EInur Latif oglu Hasanov

\section{International Scientific Journal}

\section{Theoretical \& Applied Science}

p-ISSN: 2308-4944 (print) e-ISSN: 2409-0085 (online)

Year: $2015 \quad$ Issue: $01 \quad$ Volume: 21

Published: 30.01 .2015 http://www.T-Science.org
Corresponding member of International Academy of

Ph.D. postgraduate

Institute of Local-lore of Ganja Branch Azerbaijan National Academy of Sciences,

Ganja, Azerbaijan

1-hasan@hotmail.com Theoretical and Applied Sciences,

SECTION 12. Geology. Anthropology. Archaeology.

\title{
MULTIDISCIPLINARY APPROACH TO INVESTIGATION OF THE BASIC HANDICRAFT BRANCHES OF GANJA TILL THE XX CENTURY
}

Abstract: In Ganja in a life of the population the role of craft products was great during centuries and in this scientific paper the main moments of historic-ethnographical importance of development of the main traditional branches of craftsmanship of Ganja for the first time has been systematic investigated on the basis of multidisciplinary approach. Also were researched the basic skill characteristics of different wares of these traditional handicraft branches.

Key words: handicraft branches, Ganja, historic-ethnographical research, Azerbaijan

Language: English

Citation: Hasanov EL (2015) MULTIDISCIPLINARY APPROACH TO INVESTIGATION OF THE BASIC HANDICRAFT BRANCHES OF GANJA TILL THE XX CENTURY. ISJ Theoretical \& Applied Science 01 (21): 7-15. DOI: $\underline{\text { http://dx.doi.org/10.15863/TAS.2015.01.21.2 }}$

\section{Introduction}

Research of traditional wares of handicraft kinds of Ganja on the basis of innovative methods is very important and necessary. During our researches in 2011-2013 years we determined some new scientific arguments and facts in this field. The increase in quantity of handicraftsmen in a city directly has been bundled to population growth. The competition of production of production plants and factories has not reached still serious level and consequently was created a favorable condition for spreading of traditional occupations there. Ganja city during centuries considered as one of the main urban cultures and located on the ancient caravan routes, so merchants, travelers, scientists and cultural workers from different countries of the world visited Ganja, and first of all, their visiting helped our nation to integrate their spiritual values to all mankind civilizations. Ganja is one of the oldest cities and has more than 4000 years old as an urban center. Development of some local handicraft branches in this city historically offered necessary facilities for progress of urban culture.

In middle ages in spheres of gentle and applied art, Ganja of inhabitants of territory, in agriculture life bone was widely applied. Bone products, raw materials that found during investigations in and around Ganja prove, that time bone processing separated from other spheres of craftsmanship. Osteology analysis prove, that most of samples are prepared from the bone of bull, caw, deer among big horde animals and sheep, goat, boar among little horde animals. Only deeding investigations there were found a lot of samples of combs, agriculture instruments, art and other bane things. These samples of art make more ancient history of city culture of Azerbaijan and in whole play nard. There were found knife handles, rare geometrical decorations, samples of pipe and other instruments here. During excavations there was found bone products that used as raw materials and cutting with pipe. In XI - XIII centuries this sphere of art was developing mostly. This thought is proved with a lot of bone and horn, found in zone of excavation. This period from bone there were prepared buttons, knifes and etc. Found during archeological excavations and used in wooden treatment and knife, showed that at the beginning of XI - XIII centuries in and around Ganja this sphere of craftsmanship in exist. In this period also were prepared such kind of agriculture instruments as wood shovel, rake and etc. But they didn't reach nowadays (Ofəndiyev R, 1966; Guliyeva N and Häsänov E, 2014).

In the specified period of history in Ganja developed basically carpet weaving, weaver's business, craft of the tailor, squeeze men, forge and a jeweler, trades of dyer, the stone mason, the cooper and leather dresser, weapon business and other similar craft branches. Among these crafts especially developed carpet weaving. To so wide development of carpet weaving promoted availability of raw materials. In addition carpets were very widely used 
in a population life-both as furniture, and as a curtain, both as sand bed and as a coating for a floor. It has been bundled by that in a Muslim society of the woman preferred to work in house conditions. However also know cases when men were occupied with this craft. Ganja and its surrounded territory are also rich with different stones. Presentation of white and in mountain and Aran Karabakh and also lime, traverse and marble building stones in and around Ganja, pure white, a lot of colored agates, chalcedony, veil, ametist, obsidian, agates, crystal and other kind of rare colored stones in this territory created favorable ground for developing in this ancient country from ancient times stone cutting, stone grind, stone polishing and for building great modern, columned, arched, circled and fourcornered buildings here. Similar with it, but founding stone potter with simple surface in grave kurgan number 12 also proves it.

They are similar with materials in Middle Bronze period. Founded in ruin graves cast -ironed boiler and painted spear with thin breath and length are similar for monuments of that period of Azerbaijan (Kizilveng, Aznabyurd and etc.) In Complex Borsunlu there are grinding stones with hole for hanging and mace plead, prepared from grey marble in form of pear. Borsunlu mace is differing from all other monument's mace of Azerbaijan. Maces in form of pear mostly we can see in complexes in the North Iran and South Turkmenistan, that concern to the second half of second thousand BC. Base - columns, capitals, that are symbols of irreplaceable art, part of columns, different man monuments, masonry art symbols, that have Ganja, agriculture and religious meaning, especially grave monuments and phalluses, collections of different colored (red, brown, black, grey and other rare colored) stamps and symbols of decorations, that were found in Azerbaijan during archeological investigations prove it. These rare discover in and around Ganja are known from the archaeological investigations in ancient cultural, art and trade centers of Azerbaijan. The best samples of monuments, that concern to stone treatment are consists of column props, mill and gridding stones. In whole there were founded in and around Ganja a lot of samples, that concern to X century. They are consisting of stone figure, mills and column props. But stone equipment, found in Ganja, Shamkir and Shatal prepared from mill and candlestick. Mill is usually prepared from volcanic, quartz, limestone and basalt. They used for grinding seed, millet, slot and for other aims. We meet mostly mill stones, scales and pumice stone in stone treatment. At the same time there were used hewed stones for decorating buildings. In this period there were prepared decorations from precious stone (Azorbaycan etnoqrafiyast, 2007; Nishiaki Y and Hasanov E, 2014).
Already in a number of branches finished articles have been exposed on a market. Ganja is one of the richest areas from archaeological point of view. As a result of ethno-archaeological investigations here were found samples of material culture that concerned to the stages of different history period. Today most of them are kept in various museums of the world. Archaeological investigations prove that in this period the main population of this region had sedentary lifestyle and were engaged with farming.

Scientific and archaeological researches have proved that Ganja had been the cradle of science and culture not only of Azerbaijan, but also of the whole East. Most of the natural and geographical conditions, plenty water of rivers, fertile land, rich ore deposit, fuel, wood materials used for construction and craftsmanship, colored plants for getting color and natural caves allowed the first people to live in this area in the Late Stone Age. Ganja, that has changed its location at least 4 times since its establishment, is located in a favorable position from the strategic point of view. Most of the natural and geographical conditions, plenty water of rivers, fertile land, rich ore deposit, fuel, wood materials used for construction and craftsmanship, colored plants for getting color and natural caves allowed the first people to live in this area in the Late Stone Age. The craftsmanship of carpet-making is one of the important cultural achievements of the Eastern people in Azerbaijan production of carpets appeared in the I millennium BC. But carpet - making in the first period of Middle Ages has turned to the independent sphere of craft. In Ganja, that has minimum 4000 years history, production of carpets differed with quickly development. In this ancient city, that is native land of great Azerbaijani poet and thinker Sheikh Nizami Ganjavi, were weaved very uncial, inimitable kinds of carpet. In Ganja, that has rich traditions, were prepared carpets with various characteristics. For this reason one of Azerbaijani carpet groups are Ganja carpets or (Ganja-Gazakh carpets). Pay attention that in Ganja namely local kinds of carpets-palaz (carpets without of pile) are weaved. These carpets that are producing by local inhabitants are differing with specific handicraft features. The size of Ganja's carpets begins from 3 square meters to 10 square meters. Majority of local wool products, richness of natural colors and existence professional carpetmaking women made for quick development carpet making craftsmanship in Ganja and in its surround territories.

Ganja is located on the ancient caravan routes, so merchants, travelers, scientists and cultural workers from different countries of the world visited Ganja, and first of all, their visiting helped our nation to integrate their spiritual values to all mankind civilizations. Also in XI century, during the Arab 
Caliphate flowering, the great thinker Gatran Tabrizi's population in Ganja shows, that Ganja has become a major center of culture and science in the Muslim East. From the sources it becomes clear; in that period in Ganja there were personal and public libraries, medresses as modern universities, observatories and medical centers. Muslim culture has spread to the neighboring Christian states from here. That why, many scientists, poets, architects, artists from different countries of East settled in Ganja. Also, Sheikh Nizami, appreciating Ganja's cultural level more highly, praised his native city "My Babylon". In the middle of the XII century there were schools, medresses, private and public libraries, "The houses of wisdom" and "Health centers" in Ganja. In historical sources there was information that, in Ganja there was a large library "Dar al-kutub" that had been led by a famous scientist Abulfaz al-Nakhchivani. From Sheikh Nizami's reading and the names of the works, it becomes clear, that there were rich libraries in Ganja. The high value of selcugs, that replacing arabs, to the science and culture, was the reason of formation of a new school of poetry, that was founded by Sheikh Nizami in Ganja.

Sheikh Nizami's knowledge on all the spheres of all the sciences, known at that time, show, that he has studied in madras, that belonged to the rich library, where worked well-known scientists of Ganja. The great Azerbaijani poet Sheikh Nizami had good knowledge about philosophical thoughts of such coryphaeus as Farabi, Kharezmi, Ibn Becci, Abu Ali Ibn Sina, Ibn Rusd. It shows that the language of science of that period - the Arabic language and philosophy were highly taught in Ganja. Nizami's works analysis shows, that he was familiar with the ancient Greek and Indian philosophy also. The using Al-Ustad's work "Munisname" in scientific society made deeper the level of ancient development of the Azerbaijan's literature. A short introduction of "Munisname" book is equal to the whole literary book. Abu- Bakr ibn Khosrov al-Ustad was known as knowledgeable and experienced scholar, writer and poet had knowledge on the world and shariat sciences. That why he was awarded the nickname "Ustad" (Master). In the scientific and cultural center of the East, in Ganja's literary environment were raised Abu Hafs, Abul Ganji, Abul Ula Ganjavi, Mahsati Ganjavi, Qivami Mutarrizi, Raziya Ganjavi, Mirza Shafi Vazeh, who gave priceless pearls to the treasures of world culture. Especially in that period, presence of such kind of chess-player, composer, thinker women as Mahsati Ganjavi and Raziye, who owned world science and philosophy again shows, that city from cultural point of view, stays on high level.

\section{Materials and methods}

In middle ages in spheres of gentle and applied art, Ganja of inhabitants of territory, in agriculture life bone was widely applied. Bone products, raw materials, that found during investigations in and around Ganja prove that time bone processing separated from other spheres of craftsmanship. There were found knife handles, rare geometrical decorations, samples of pipe and other instruments here. During excavations there was found bone products that used as raw materials and cutting with pipe. In XI-XIII centuries this sphere of art was developing mostly. This thought is proved with a lot of bone and horn, found in zone of excavation. This period from bone there were prepared buttons, knifes and etc. Found during archeological excavations and used in wooden treatment and knife, showed that at the beginning of XI - XIII in and around Ganja this sphere of craftsmanship in exist. All these aspects show, that inhabitant of Middle Ages in and around Ganja from the ancient period did masonry, gridding and stone treatment. This sphere of art in developed middle Ages could be in high level. And rare magnificent architectural monuments in and around Ganja that stay till nowadays, prove it (Ofəndiyev R, 1966; Guliyeva N and Häsänov E, 2014).

Traditional textile of art of silk weaving products has a special place in Ganja. In the city formed two main method of silk treatment:

\section{Spinning.}

2. Winding.

From the point of view silkworm breeding development and its preparing technology there were two main forms of production: so-called raw silk weaving and felt weaving .In this important technological processes it has such kind of production stages as cocoon opening, silk initial processing ,preparing of raw silk, weaving technology, painting and decoration.

In the ancient Ganja during the stage of the Middle Ages the great progress of silkworm was represented by raw silk weaving. For this reason, on the basis of local traditions production of delicate silk textiles from raw silk. There were made such kind of important samples of art as atlas and kelaqai (silk kerchief). We must pay attention to the moment that differs from the other silk fabrics, kelaqai was prepared by specialists. But distinctly of production of raw silk, that was city silkworm breeding and was man activity, felt production was woman work. In Ganja, that know as the ancient cultural center, the saddle-making handicraft differed from others with rich old traditions. First time preparation of the vehicles was house profession. But afterwards saddle preparation needed of qualified skilled masters, so a new type of art saddle-making, started to form. Historically the traditional art of saddle-making in Ganja developed in direction of cargo and passenger saddle making. 
The art of saddle-making within the local saddle-types and their components were determined on a specialization. The production of cargo or pack -saddle a rule was engaged by pack-saddle maker. For this reason, in most cases, the profession was called trade of pack-saddle maker. Tailors and hatters created both national clothes, and clothes in style of the European fashion. According to the spent explorations there are exact data on wide development of a jeweler in Ganja in the end of XIX century - in a beginning of XX centuries. Jewelers basically fabricated ornaments to order. Among them there was a specification. Jobs of skilful masters amazed even foreigners. Development of trading and economic relations of Ganja with the next states promoted recognition of local jewels abroad. As an example it is served by unique samples handmade the Azerbaijan jewelers, stored in museums of the world (Azarbaycan etnoqrafiyasl, 2007; Nishiaki Y and Hasanov E, 2014).

In addition, products of these craft branches have been closely bundled to a life and traditions of the people, and it would be difficult to replace with their factory production. Traditional spheres of crafts are invaluable and reliable sources of studying of culture, aesthetic taste, outlook (world outlook) of the Azerbaijan people. Ethnographic and anthropologic exploration of problems and branches of crafts very important, as a way of studying along with history and culture of the people, years generated political-economical and relations of production. Closely bundled to an economy and a daily life of the people, craft employment were one of the basic carriers of national traditions. In the first half of the XVIII-XIX centuries, as well as in other parts of Azerbaijan, in Ganja household objects, forging weapons and jewelries that made from metal were decorated with different technical ways. As in many places, production of wool, cotton and silk in and around Ganja made necessary emergence and development of weaving. Becoming weaving one of the ancient spheres of crafts in and around Ganja was connected with the rich raw material base here. Presence of useful plant species for textile, including cotton, high level development of wool area of agriculture-sheep and goat breeding, camel breeding, horse breeding, presence of cotton cropping in Middle Ages and finally, regular expansion of silkworm breeding in this area created a foundation for growth of weaving here. In addition, during the research work in Ganjabasar and other territories monuments there have been found whole and parts of weaving loom and different sizes of clay and bone samples that consist to weaving.

Among these types of craft metal treatment is mostly developed and has ancient history. Abundance of local raw materials created favorable conditions for development of metal treatment from ancient times. In general, in the third millennium $\mathrm{BC}$ there was high culture of the Bronze Age in our country, and in the first millennium transition period from Bronze Age to Iron Age began. In that period in Azerbaijan there were appeared several branches of metallurgy treatment. Jewelries, daggers, arms, copper products and other samples of art have been treated so refined, that in nowadays they are protected as very valuable exhibits in famous museums in such cities, as Paris, London, Brussels, Istanbul, Tehran and other cities. There is no any source about glass production in and around Ganja. The majority of archaeologists agreed with the idea, that the homeland of glass production is ancient Egypt, but the famous English archaeologist, Egyptologist Petri Flinders thought, that it could be Mesopotamia or the Caucasus. Taking into account that cobalt, used in glass coloring wasn't in Egypt, the scientists thought that, it could be in the Caucasus, also in Dashkesan. The majority of containers and the analysis based on graphical elements of the Roman scholars came to the opinion that the samples of the same scale as the Roman Empire through trade.

There are more than 2000 beads in complex materials. Colored beads have prepared of different types products. Mostly distinguish beads that prepared from blue green and grey paste. A group of beads made of bone and antimony. In III-V centuries, the local craftsmen themselves also became to produce better-designed containers. Among the local clay and glass utensils that found in and around Ganja there were big similarity in the form and also in the decoration. Produced glass alloys were transparent colored. By the addition of dusts of various metals in glass alloys people got colored glasses. We can see also to get her with different tinted green glasses also parts of blue, black and pink colored glass dish in sections of IX-X centuries. Among decorations of that period yellow, white and red beads of round and plain form are met mostly. At the beginning of X-XIII centuries development of production of glass in and around Ganja characterized by improvement from the technology point of view. Archaeological researches show, that outside of the cities in the VIII-IX centuries, also big settlements were established. This is often due to density in cities. From the point of view silkworm breeding development and its preparing technology there were two main forms of production: so-called raw silk weaving and felt weaving. In these important technological processes it has such kind of production stages as cocoon opening, silk initial processing, preparing of raw silk, weaving technology, painting and decoration. In the ancient Ganja during the stage of the Middle But distinctly of production of raw silk that was city silkworm breeding and was man activity, felt production was woman work. In Ganja, that know as the ancient cultural center, the saddle-making handicraft differed 
from others with rich old traditions. First time preparation of the vehicles was house profession. But afterwards saddle preparation needed of qualified skilled masters, so a new type of art saddle-making, started to form. Historically the traditional art of saddle-making in Ganja developed in direction of cargo and passenger saddle making. The art of saddle-making within the local saddle-types and their components were determined on a specialization. The production of cargo or pack-saddle a rule was engaged by pack-saddle maker. For this reason, in most cases, the profession was called trade of packsaddle maker (Ofəndiyev R, 1966; Guliyeva N and Häsänov E, 2014).

In the territory of Azerbaijan the oldest samples of wood treatment were found in the territory of ancient Ganja. Around Ganja area - in the region of Lake Goy-gol in the IV-III millennium BC have been discovered wooden thicker board, also wooden sugar bowl, that concern to the end of the II millennium $\mathrm{BC}$, found in Mingachevir pitcher grave are material evidences of science thoughts. First of all, there have been discovered, that initial ceramic production in Ganja and its surrounding regions are belong to the VIII-VII millennium BC. From the history point of view, these ancient clay vessels, belonging to the Neolithic stage, are differing from the pottery samples of the neighboring ethnic in number characteristics. These differences are seen in preparing technology, also in the area of external surface decoration.

In this historical period in Ganja and its regions ceramic has following kinds:

1. Building ceramic materials.

2. Unglazed ceramic products.

3. Glazed ceramic products.

For Middle Ages and New period among pottery products of Ganja ceramic samples as clay construction materials have great importance. First of all, glazed bricks that used in construction of most buildings in the XVII-XVIII centuries, and also in great monuments and the main construction materialair-dried bricks, attracted attention. In addition to the found samples in residential areas as a result of archaeological excavations, also were found a lot of brick spoilages. According to such kind mass finding of brick spoilages, we can make the conclusion, that the bricks used in construction of buildings in Ganja, were wares of local production.

Research of traditional wares of handicraft kinds of Ganja till XX century on the basis of innovative methods is very important and necessary. The increase in quantity of handicraftsmen in a city directly has been bundled to population growth. Closely bundled to an economy and a daily life of the people, craft employment were one of the basic carriers of national traditions. The competition of production of production plants and factories has not reached still serious level and consequently was created a favorable condition for spreading of traditional occupations there. In addition, products of these craft branches have been closely bundled to a life and traditions of the people, and it would be difficult to replace with their factory production (Guliyeva N and Häsänov E, 2014). In the specified period of history in Ganja developed basically carpet weaving, weaver's business, craft of the tailor, squeeze men, forge and a jeweler, trades of dyer, the stone mason, the cooper and leather dresser, weapon business and other similar craft branches.

\section{Solving methods of problem and testing}

During our researches in 2012-2013 years we determined some new scientific arguments and facts in this field.

A) Wood treatment products historically have been represented in various fields of social and cultural life in Ganja: Kitchen appliances: trough, quadruped, rolling-pin, mortar and pestle, ladle, spoon, trough.

B) The majority of historical monuments, that are demonstrate the 4000 thousand year history of Ganja, which is the national wealth of our people, today gain unique place in the expositions of world's museums. In state and private museums of Metropolis, Munich, Berlin, Hamburg, Louvre, Paris, Moscow, St. Petersburg and other cities rare and valuable exhibits, that concern to the history of ancient Ganja are preserved.

C) The formation of pottery on the territory of ancient Ganja is concern to the stages of ancient history. Basis on research works carried out by the various persons in XIX century and expertsarcheologists at the beginning of XX century in old ruins of the city and surrounding areas there were found different samples of pottery.

D) As in many places, production of wool, cotton and silk in and around Ganja made necessary emergence and development of weaving. Becoming weaving one of the ancient spheres of crafts in and around Ganja was connected with the rich raw material base here.

E) Presence of useful plant species for textile, including cotton, high level development of wool area of agriculture- sheep and goat breeding, camel breeding, horse breeding, presence of cotton cropping in Middle Ages and finally, regular expansion of silkworm breeding in this area created a foundation for growth of weaving here.

F) In traditional production of cloth manufactory trade historically played an important place. This kind of craft that developed on the basis of local raw materials was tied with cottongrowing economy. Since the time of the early Middle Ages, Ganja as other great cities have 
been the main center of Azerbaijan in production of cotton cloth.

G) Research of the main traditional craft branches on the basis of new, innovative methods and technologies is very important. Results of these researches show the significance of different patterns of craftsmanship kinds as a source in studying of historical past of nations.

Historic and ethnographic exploration of problems and branches of crafts is very important, as a way of studying along with history and culture of the people, years generated political-economical and relations of production. These products were widely used inhabitants of Ganja they decorated conditions of living rooms, with them filled up a dowry of brides. The dresses created in local departments, suits and caps were an integral part of an attire of towndwellers. In comparison with villages though the national clothes in XX century began to supersede them gradually. It also has been bundled to accruing arrival to Ganja representatives of other nationalities. Therefore changes in clothes were more marked. Only female ornaments as an attire constituent part left the national feature. At this time there were fashionable ornaments on a breast, hands, set pins and on clothes. The increase in quantity of handicraftsmen in a city directly has been bundled to population growth.

Tailors and hatters created both national clothes, and clothes in style of the European fashion. According to the spent explorations there are exact data on wide development of a jeweler in Ganja in the end of XIX century - in a beginning of XX centuries. Jewelers basically fabricated ornaments to order. Among them there was a specification. Jobs of skilful masters amazed even foreigners. Development of trading and economic relations of Ganja with the next states promoted recognition of local jewels abroad. In Ganja, that know as the ancient cultural center, the saddle-making handicraft differed from others with rich old traditions. First time preparation of the vehicles was house profession. But afterwards saddle preparation needed of qualified skilled masters, so a new type of art saddle-making, started to form. Historically the traditional art of saddle-making in Ganja developed in direction of cargo and passenger saddle making. The art of saddle-making within the local saddletypes and their components were determined on a specialization. The production of cargo or packsaddle a rule was engaged by pack-saddle maker. For this reason, in most cases, the profession was called trade of pack-saddle maker (Ohmədov F, 2007).

All the glass dishes found in and around Ganja are similar with the local clays on decoration of that period. Glass dishes were containing of Iron, cobalt, magnesium and other elements, that were specific elements for Ganja and its surroundings. The development history of this sphere of craftsmanship can be determined only through archaeological research.

Distribution of experts of certain crafts on quarters and neighboring communes was prominent of crafts. For example, it is possible to recollect. In these neighboring communes functioned craft departments. On a ground classifying crafts it has been defined that by the end of XIX century a number of fashionable trades began to disappear. They have got rid of and have been replaced by representatives of new crafts (Hasanov E, 2014).

\section{Discussion of results and applicative significance}

I. Internal conditions of craft department reflected a sort of employment of his owner. In these departments worked the master and his pupils. In a life of the population of Ganja the role of craft products was great. These products were widely used inhabitants of Ganja they decorated conditions of living rooms, with them filled up a dowry of brides. The dresses created in local departments, suits and caps were an integral part of an attire of town-dwellers. In comparison with villages though the national clothes in XX century began to supersede them gradually. It also has been bundled to accruing arrival to Ganja representatives of other nationalities. Therefore changes in clothes were more marked. Only female ornaments as an attire constituent part left the national feature. At this time there were fashionable ornaments on a breast, hands, set pins and on clothes (Häsänov E, 2014).

II. Investigation of the main traditional craft branches on the basis of new, innovative methods and technologies is very important. Results of these researches show the significance of different patterns of craftsmanship kinds as a source in studying of historical past of nations.

III. Studying of craft problems actually and in the modern world in sense of the decision of professional problems. From the investigated national employment carpet weaving, the jeweler, a stone dressing and strenuously develop on the basis of ancient traditions already dying out ancient trades, such as a pottery and an art embroidery. Each area of Azerbaijan possesses characteristic environmental resource bases for it and it promoted development of various crafts. Thus, a number of employments in Ganja, during the period since XIX century to the middle of XX century, differed from crafts of other areas of the country. It was first of all the trades bundled to a spreading of a city and population grown has increased demand for craft products. Under such circumstances the handicraft work could 
not keep the natural character (Azerbaijan ethnography, 2007).

IV. In traditional production of cloth manufactory trade historically played an important place. This kind of craft that developed on the basis of local raw materials was tied with cottongrowing economy. Since the time of the early Middle Ages, Ganja as other big cities has been the main center of Azerbaijan in production of cotton cloth. In this ancient city printed cotton and calico fabrics have been widely produced. In traditional cloth productions the main place took the urban mines (Smith W and Hasanov E, 2013).

Investigation of traditional wares of handicraft kinds of Ganja on the basis of innovative methods is very important and necessary. During our researches in 2012-2013 years we determined some new scientific arguments and facts in this field and in the future we shall continue our investigations.

\section{Importance of application of innovative technologies and methods}

In scientific work for the first time has been researched the significance of traditional craftsmanship patterns from ethnographic and archaeological point of view in investigation of development of features of urban culture in Ganja on the basis of scientific arguments. Were noted the main results of investigations of local researchers in this field with scientists from the USA and Japan on the basis of application of innovative technologies and methods. These scientific investigations have a great applicative significance. It is possible of production of these handicraft wares for ancient, classical and Mediavel periods on the basis of its production technology and materials in the modern time as new models.

In the territory of ancient Ganja during the end of 2012 - in 2013 have been carried out scientific researches, archaeologic and ethnographical investigations by local scientists together with researchers from National Museum of Natural History of Smithsonian Institution of the USA and Tokio Museum University of Japan with the purpose to study of historical formation and development of Urban culture. Because, one of the areas of initially appeared human civilization was an integral part of Azerbaijan, the historical land of the city Ganja. Scientific and archaeological researches have proved that Ganja was cradle of science and culture not only of Azerbaijan, but also of the whole East. The majority of historical monuments, that are demonstrate the ancient history of Ganja, which is the national wealth of our people, today gain unique place in the expositions of World's museums.

The main aim of our international investigations for the second half of 2013 with scientists from the
US and Japan is research of significance of local traditional handicraft patterns as a source in research of features of urban culture in Ganja. As known, Ganjabasar is one of the richest areas from archaeological point of view. As a result of archaeological investigations here were found samples of material culture that concerned to the stages of different history period. Today most of them are kept in various museums of the World (Azerbaijan ethnography, 2007). Basic objective of this innovative research is outreach, also publish in international academic journals of the main results of scientific researches in this field on the basis of application of innovative technologies and methods. Research of traditional wares of handicraft kinds of Ganja on the basis of innovative methods is very important and necessary. The increase in quantity of handicraftsmen in a city directly has been bundled to population growth. Closely bundled to an economy and a daily life of the people, craft employment were one of the basic carriers of national traditions. The competition of production of production plants and factories has not reached still serious level and consequently was created a favorable condition for spreading of traditional occupations there. In addition, products of these craft branches have been closely bundled to a life and traditions of the people, and it would be difficult to replace with their factory production (Guliyeva N and Häsänov E, 2014). In the specified period of history in Ganja developed basically carpet weaving, weaver's business, craft of the tailor, squeeze men, forge and a jeweler, trades of dyer, the stone mason, the cooper and leather dresser, weapon business and other similar craft branches.

During these scientific investigations have been used some main innovative academic methods:

1. Application of biochemical innovative technologic methods (as radiocarbon, dendrochronologic methods and etc.);

2. Research of local materials of craftsmanship patterns;

3. Determination of traditional methods and materials of handicraft wares on the basis of innovative roads;

4. For the first time research of problem of genesis of handicraft traditions on the basis of production technology and technique of local craftsmanship patterns of ancient and classical periods;

5. Foundation of the new scientific direction on ethnography and ethnology on the basis of investigation of sustainable historical features of handicraft branches in research of the historical past of formation and development of Urban culture;

6. Investigation of importance of the handicraft patterns as the main source in research of characteristics of formation and development of Urban culture (formation process of the features 
of urban culture) for ancient and classical periods on the basis of scientific arguments.

7. For the first time has been researched the significance of traditional craftsmanship patterns from ethnographic and archaeological point of view in investigation of development of features of urban culture in Ganja on the basis of scientific arguments.

8. Were noted the main results of investigations of local researchers in this field with scientists from the USA and Japan on the basis of application of innovative technologies and methods.

9. In the future it would help to continue the both scientific-research works, also ethnographic and archaeological investigations, excavations and for the main academic results in this field.

10. These scientific investigations have a great applicative significance. It is possible of production of these handicraft wares for ancient, classical and Mediavel periods on the basis of its production technology and materials in the modern time as new models.

\section{Conclusion}

a) In whole at the beginning of XIX-XX century the quality of carpet craftsmen were more than XX thousand. Such kind of carpets without pile as phalas, kilim, holdall, bead, verni, sumach, heybe, carpet - bag were different with qualities and colored ornamental elements. Especially we must say that Ganja carpets have always been valued for its quality and art characteristics. As the result of in XIX - XX centuries most of Ganja carpets were showed in world in fluent exhibition. Ganja carpets were showed and highly in international exhibition. Nowadays, Ganja's carpets are kept in authoritative museums of world, and also in collection of different people. The studying of Ganja's carpets for art characteristics quality form science point of view is very important for investigation heritage of world culture (The dawn of Art. 1974).

b) Wood treatment products historically have been represented in various fields of social and cultural life in Ganja as the kitchen appliances: trough, quadruped, rolling-pin, mortar and pestle, ladle, spoon, trough, also transport means: sleigh, car, and ski. Weaving tools: comb, face. Household tools: harrow, wooden plow, threshing board, spade, wooden shouvel, pitchfork and rake. Musical instruments: saz, ud, tar, chamahcha, tambourine, drum (Guliyeva N and Häsänov E, 2014).

c) The formation of pottery on the territory of ancient Ganja is concern to the stages of ancient history. Basis on research works carried out by the various persons in XIX century and experts- archeologists at the beginning of XX century in old ruins of the city and surrounding areas there were found different samples of pottery. From the construction point of view, samples of pottery, that concern to Antique period, also to the period of Hellenism in Ganja, differed in various forms as pictorial vases, ceramic figures, connected dishes. During the end of Middle Ages and New Period in Ganja and its regions ceramic has following kinds as building ceramic materials, unglazed ceramic products, glazed ceramic products. For Middle Ages and New period among pottery products of Ganja ceramic samples as clay construction materials have great importance. First of all, glazed bricks that used in construction of most buildings in the XVII-XVIII centuries, and also in great monuments and the main construction material - air-dried bricks, attracted attention. In addition to the found samples in residential areas as a result of archaeological excavations, also were found a lot of brick spoilages. According to such kind mass finding of brick spoilages, we can make the conclusion, that the bricks used in construction of buildings in Ganja, were wares of local production (Azerbaijan ethnography, 2007).

In the first half of the XVIII-XIX centuries, as well as in other parts of Azerbaijan, in Ganja household objects, forging weapons and jewelries that made from metal were decorated with different technical ways. As in many places, production of wool, cotton and silk in and around Ganja made necessary emergence and development of weaving. Becoming weaving one of the ancient spheres of crafts in and around Ganja was connected with the rich raw material base here. Presence of useful plant species for textile, including cotton, high level development of wool area of agriculture-sheep and goat breeding, camel breeding, horse breeding, presence of cotton cropping in Middle Ages and finally, regular expansion of silkworm breeding in this area created a foundation for growth of weaving here.

Investigation of the main traditional craft branches on the basis of new, innovative methods and technologies is very important. Results of these researches show the significance of different patterns of craftsmanship kinds as a source in studying of historical past of nations. Studying of craft problems actually and in the modern world in sense of the decision of professional problems. From the investigated national employment carpet weaving, the jeweler, a stone dressing and strenuously develop on the basis of ancient traditions already dying out ancient trades, such as a pottery and an art embroidery. Each area of Azerbaijan possesses 
characteristic environmental resource bases for it and it promoted development of various crafts.

\section{References:}

1. Azrrbaycan etnoqrafiyası (2007) 3 cilddə, I c., Bak1: Şərq-Qərb. 544 s.

2. Bünyadova ST (1992) Nizami vo etnoqrafiya. Bak1: Elm.

3. Burton-Brown $\mathrm{T}$ (1951) Excavations in Azerbaijan, 1948. London.

4. Ohmədov FM (2007) Gəncənin tarix yaddaşı. Gəncə: Elm.

5. Ofəndiyev RS (1966) Azarbaycanın badii sənətkarlı̆̆ı. Bakı: Azərnəşr.

6. Guliyeva NM, Häsänov EL (2014) Die traditionelle Gändschänischen Teppiche von Zeitraum der Aserbaidschanischen Gelehrten und Dichter Mirsä Schäfi Waseh als ethnoanthropologische quelle (XIX Jahrhundert). European Applied Sciences, 2: 3-5.

7. Guliyeva NM, Hasanov EL (2013) About ethno demographic description of large family and patronymics in Ganja of the XX century. ISJ Theoretical \& Applied Science 12(8): 38-40. doi:

http://dx.doi.org/10.15863/TAS.2013.12.8.9

8. Hasanov EL (2013) Innovative approach to teaching and research of some traditional craft branches of Ganja of the end of XIX century. International Journal of Experimental Education 2: 81-83.
9. Hasanov EL (2014) Approccio innovativo per lo studio scientifico delle tradizioni artigianali grandi Ganja seconda metà del XIX-inizi XX secolo. Italian Science Review, 4: 642-645.

10. Həmidova İ (2000) Azərbaycan parça sənətinin tarixi inkişaf yolları. Elmi axtarışlar, VIII toplu, Bakı.

11. Həvilov HA (1991) Azorbaycan etnoqrafiyast. Bak1: Elm.

12. Nishiaki Y, Hasanov EL (2014) About ethnoarchaeological and anthropological research of some prehistoric monuments of Ganja. ISJ Theoretical \& Applied Science, 01 (9): 45-48. doi:

http://dx.doi.org/10.15863/TAS.2014.01.9.8

13. Smith WB, Hasanov EL (2013) Importance of handicraft traditions in investigation of history of urban culture in Ganja. ISJ Theoretical \& Applied Science 11(7): 61-66. doi: http://dx.doi.org/10.15863/TAS.2013.11.7.10

14. Torlanov M, Ofondiyev R (1960) Azarbaycan xalq sənəti. Bakı: Uşaq gənc nəşr.

15. The dawn of Art (1974) Leningrad: Aurora Art Publishers. 